\title{
Refugee health reforms assailed
}

A desire to dissuade "bogus" refugee claims, public envy over the level of health care that asylum seekers receive, and cost savings are ample justification for limitations on hospital, physician and other medical services provided to refugee claimants and protected persons, Minister of Citizenship, Immigration and Multiculturalism Jason Kenney says.

"The largest source of asylum claimants is the European Union," Kenney added in an interview. "Virtually none of these claimants ever show up for their hearings and virtually all of the claims are abandoned or withdrawn. So we need to work with some of the pull factors for asylum claimants who are coming from countries that are not known to produce refugees."

Moreover, the public is demanding such limitations, Kenney says. "We've received a lot of feedback from Canadians that they don't think we should be providing health benefits to asylum claimants that are better than Canadians get from provincial health insurance programs."

Utter hogwash, counter angry physicians opposed to the restriction on services to those that are "of an urgent or essential nature" (www.cmaj.ca/lookup /doi/10.1503/cmaj.109-4203). Refugee claimants will also be denied medications and vaccines unless they pose a public health threat, while rejected claimants or people from nations on a Designated Countries of Origin list (which "do not normally produce refugees") will not receive any health care unless there is a public health threat (www.gazette.gc.ca/rp-pr/p2/2012/2012 -04-25/html/si-tr26-eng.html).
It's inhumane, says Dr. Philip Berger, chief of the Department of Family and Community Medicine at St. Michael's Hospital at the University of Toronto in Ontario. "The state has issued guidelines on the practice of medicine that is totally unrelated to the interests and welfare of patients," he says. The government has "usurped the professional judgment and discretion of physicians and taken it on themselves. Minister Kenney just doesn't want to pay for vulnerable people. It's as simple as that."

Kenney rejects that charge as "specious. It's not a political use of health care. It's rather a reflection of the fact that we have scarce resources, and we need to focus our public health care resources on Canadian residents who pay their taxes and on bona fide refugees."

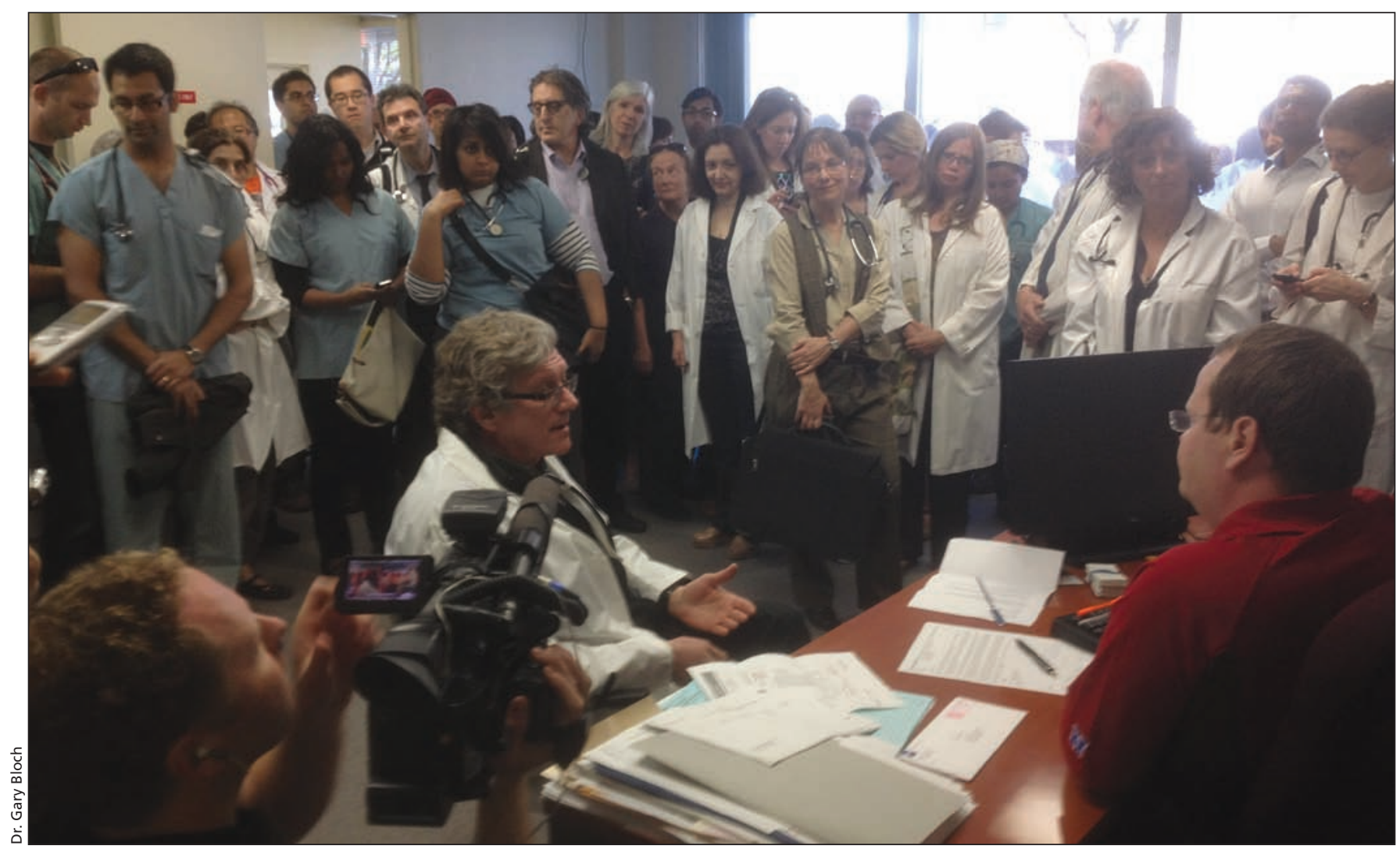

Dr. Philip Berger leads 50 physicians in a sit-in at the Toronto, Ontario office of federal Natural Resources Minister Joe Oliver on May 11. An additional 40 physicians protested outside. For a video of their demonstration, see: www.youtube.com/watch?v=RiNDtUaNudk 
The Interim Federal Health Program (IFHP), which served 128000 clients in fiscal 2011/12, has lost its founding purpose, Kenney adds. "The IFHP was created as a very short-term and modest program to cover initial health care costs for displaced persons coming to Canada. It's expanded ever since then and the costs in particular have ballooned. It's almost doubled in cost over the past five or six years to about $\$ 98$-million a year. And so we wanted to review it from a cost-management point of view."

But Berger and other physicians, who organized coordinated May 11 protests in Toronto, Ottawa, Ontario and Winnipeg, Manitoba against the changes, including a sit-in at the Toronto office of Natural Resources Minister Joe Oliver, reject Kenney's arguments and accuse the federal government of trying to offload costs onto the provinces.

There's no evidence of wholesale abuse of the system, argues Dr. Meb Rashid, medical director of the Crossroads Clinic at Women's College Hospital in Toronto. "I've seen over 2000 refugee claimants and I can't recall more than a handful who strike me as being wealthy or here for adventure. The government is painting them to be bogus and cheating the system. That really hasn't been my experience."

Berger concurs. "I've never met a single refugee who comes here to take advantage of Canada's health care system. They come because they're fleeing torture, rape and violence," he says, arguing that the government has fabricated an "artificial confrontation" between refugee claimants and Canadians. "The government has a wholly misinformed and misguided view that introducing punitive measures against all refugees will somehow dissuade refugees who have manifestly unfounded claims."

The government's contention that the changes will trim overall IFHP expenditures by an aggregate $\$ 70$ million over the next three years and an average \$15 million annually thereafter, won't result in savings to taxpayers as the changes will simply drive up hospi- tal emergency department costs, the physicians say.

"I wouldn't be surprised if this costs more" by driving up emergency department costs, particularly when the health consequences of discontinuing funding for medications such as insulin and antihypertensives begin to emerge, Rashid says. "If they actually sat down and itemized the costs of DKA [diabetic ketoacidosis] and uncontrolled hypertension it would be quite chilling. And those are calculations that shouldn't be driven by costs alone."

Kenney, however, rejects the proposition that the changes will constitute a blow to hospital and provincial budgets. "First of all, the overall expenditure on the IFHP is a tiny fraction [0.04\%] of a percentage of total health expenditure in Canada ... So I think they're exaggerating the costs of this clientele. Secondly, this argument could be made about a foreign national who happens to be visiting Canada and shows up at the hospital and doesn't have insurance - the hospital is probably going to get stuck with the tab. That's a reality of being a known country where people are coming and going."

Moreover, he says, cost savings will accrue from a reduction in bogus refugee claims, particularly from Designated Countries of Origin.

But Rashid surmises that the real motivation behind the changes is to deter refugees, while Berger accuses Kenney of "bullying those who are defenseless, and that's the reason doctors are speaking up in such numbers. When Minister Kenney stops practicing medicine, the doctors will stop protesting."

The physicians are also disturbed by specifics contained within a Citizenship and Immigration Canada guide to help health care professionals navigate the reforms (www.cic.gc.ca/english/refugees /outside/coverage.asp).

For example, the guide indicates that rejected claimants and people from Designated Countries of Origin should not receive coverage for acute myocardial infarctions. That's "chilling," says Berger.
"Nowhere have I ever read a government document that lists treatment for a heart attack as "none". "It will be a document for the history books. It will be a document that will be studied when academics look at the state's use of medicine for political purposes."

That runs counter to the humanitarian instincts of Canadians, he adds. "Canadians are fair-minded people that would never accept turning anybody down, whether refugee or tourist or citizen, when they're suffering from a heart attack."

The physicians are also concerned the reforms will prove cumbersome for clinicians to navigate as they'll constantly have to determine whether a claimant qualifies for a procedure and whether that service falls under the ambit of the reforms.

"You can imagine the orthopedic surgeon sitting there saying: 'Is this fracture covered'?" notes Rashid. "How would you go through all the possible scenarios? I imagine people will be turned away. It will be a catastrophe. ... Most docs will have no idea who is covered and for what. I'm quite confident that most will simply stop seeing refugee patients."

But Kenney says the government has made things easy for clinicians by putting the criteria online through a service provider, Medavie Blue Cross. "It should be fairly simple and straightforward."

Not so simple when a physician has to determine whether someone qualifies without the aid of diagnostic testing, Berger notes. It will "put doctors in a Kafkaesque knot" as labs won't be willing to absorb the cost.

The upshot will be that "patients with active TB [tuberculosis] will [only] be diagnosed when they show up wasted and coughing up blood in an emergency department," he adds. "Ironically Minister Kenney's policy will increase the risk to public health." Nathan Stall, Toronto, Ont.

CMAJ 2012. DOI:10.1503/cmaj.109-4208 